\title{
Range research in the far western United States: the first generation
}

\author{
JAMES A. YOUNG
}

The author is range scientist, USDA, Agricultural Research Service, 920 Valley Road, Reno, Nevada 89512.

\begin{abstract}
The scientific study of rangelands in the western United States, started with the first collection of natural history specimens in the 18 th century. Gradually over the 19 th century, a basic catalog of the plants, animals, and geography of the far west was assembled. After the U. S. Department of Agriculture (USDA) was organized, scientists were sent to the western ranges on factfinding missions designed to assess the existing range livestock industry and its potential. At the turn of the 19th to the 20th century, a few visionary scientist began to conduct actual experiments in rangeland environments. The Forest Service, USDA, was established in 1905, and what had been Forest Reserves from the U. S. Department of Interior (USDI) were transferred to the new agency. It was responsible for sustainable timber product and watershed management on millions of acres of wild lands. The Forest Service soon discovered that livestock grazed on fourfifths of the National Forest land and it was estimated that $85 \%$ of these rangelands were over-grazed and subject to accelerated erosion. The Forest Service started preliminary research on rangelands in 1907 and formally started an Office of Grazing Studies in 1910. Beginning with the Great Basin Experiment Station in 1912, a series of stations were developed by the Forest Service. As agricultural experiment stations developed at Land Grant colleges in the western states, state sponsored research on rangelands increased in importance.
\end{abstract}

Key Words: History, Forest Service, Experiment Stations, range ecology

The basic concepts of what we know as range science were formulated early in the 20th century. They often were formulated out of necessity as the nation faced precipitous declines in productivity from the western range in association with accelerated erosion. In the far west, the growth in range science was contemporaneous with the establishment of the Federal range, vast acerages of rangeland managed by agencies of the Federal government. The demands placed upon rangeland resources have changed during the 20th century, but the scientific basis for range management has remained relatively constant. The scientific basis of range management has always been open to a variety of interpretations. How these interpretations were originally made, how such interpretations have changed over time, and the outside influences that may have shaped such decisions are the intricate fabric of the history of range science. By assignment, this presentation was restricted to the mountainous and intermoutain portions of the west. The constraints of time and manuscript length have resulted in a lack of emphasis on the range research con-

Manuscript accepted 17 July 1999.

\section{Resumen}

En el oeste de los Estados Unidos el estudio científico de los pastizales inicio en el siglo 18 con la primer colección de especímes de historia natural. Gradualmente, en el siglo 19, se conformó el primer catálogo básico de plantas, animales y geografía del lejano oeste de los Estados Unidos. Posteriormente, el Departamento de Agricultura de los Estados Unidos fue organizado y se enviaron científicos a los pastizales del oeste en misiones para estudiar y evaluar la industria ganadera existente en los pastizales y su potencial. A fines del siglo 19 e inicios del siglo 20, unos pocos científicos visionarios iniciaron la conducción de los experimentos actuales en pastizales. El Servicio Forestal del Servicio de Agricultura de los Estados Unidos se estableció en 1905, y lo que habían sido las reservas forestales del Departamento del Interior de Estadios Unidos se transfirieron a la nueva agencia. El Servicio Forestal era responsable del uso sutentable de los productos forestales y el manejo de las cuencas hidrológicas en millones de acres de tierras no colonizadas. El Servicio Forestal pronto descubrió que el ganado apacentaba cuatro quintas partes de la tierra de los bosques nacionales, y estimó que el $85 \%$ de estos pastizales estaban sobreutilizados y sujetos a una erosión acelerada. En 1907, el Servicio Forestal inicia investigaciones preliminares en los pastizales y en 1910 inicio formalmente una oficina de estudios de apacentamiento. Iniciando con la Estación Experimental Great Basins en 1912, el Servicio Forestal desarrollo una serie de estaciones experimentales fundadas como estaciones experimentales agrícolas en las universidades de los estados del oeste y el estado financio la investigación en pastizales y esta aumento en importancia.

ducted in the Southwestern portion of the United States, but in no way is meant slight the significant achievements made in range science in that region.

The period of range research we wish to review can be subdivided into logical, but unequal length intervals: 1) exploration of the west, enumeration of the resource; 2) agricultural surveys; 3 ) visionary scientists; and 4) establishment and development of the Forest Service.

\section{Exploration of the West: Enumeration of the Resource}

Before you can manage the resource, you have to know its component parts. We have, through education and experience, accepted that the basic units of rangeland environments are the assemblages of plants and soils plus the animals they support. To 
communicate knowledge about the environment, the components must have near universally recognizable names. In the mid 19th century when the range livestock industry was expanding through the far west, many of the plants, some of the animals, and virtually all of the soils did not have such names.

Biological explorers came to the far western range for a variety of reasons. The great botanical gardens of England and Scotland sent botanical collectors such as David Douglas to the American west in search of specimens for their herbariums and gardens and for potential economic cultivars. In the process the plants were classified, given binomial names, descriptions published, and type specimens were filed in herbariums. Often the collections included at least rudimentary descriptions of the sites where the plants were collected.

If we had to pick one botanist of the early 19 th century to represent the scientific enumeration of the resources of what became the western range, perhaps it should be Fredrick Traugott Pursh. He did not face the hazards of collecting in the western wilderness, but he was the first to describe such pillars of range management as bluebunch wheatgrass [Pseudorogneria spicata (Pursh) A. Love] and antelope bitterbrush [Purshia tridentata (Pursh) DC.]. Collected on the "Plains of the Columbia" these specimens were transported by the members of the Lewis and Clark Expedition back across the Rocky Mountains and down the Missouri River and eventually to Pursh at Philadelphia.

Much of the formal exploration of the American west during the 19th century was conducted by the Corps of Engineers, U. S. Army. The topographic engineers who explored the west sometimes acted as biological collectors while other expeditions included trained naturalists as members. One of the later and most intensive surveys was that led by First Lieutenant George M. Wheeler under the auspices of United States Geographical Surveys West of the One Hundredth Meridian. The survey results were reported in 7 volumes with titles ranging from geographical reports to archaeology. Volume 6 was Botany under the editorship of Joseph Trimble Rothrock (1878). He was born in 1839 and served on the Wheeler Survey as surgeon and botanist. Contributors to the botany volume included Sereno Watson, George Engelmann and George Vasey. These names are abundantly recognized in both specific names and authorities for western range plants.

Grasses have always been considered the backbone of forage resources on most cattle ranges. Starting with the botanical magnificence of the Great Plains, agrostologists worked westward through the mountain slopes, meadows and deserts collecting, preserving and often describing type specimens of grasses. Outstanding among the early agrostologists were George Vasey and F. Lamson-Scribner (sometimes given as F. L. Scribner). Vasey (1890) published Illustrations of North American Grasses and Grasses of the Southwest. Lamson-Scribner (for example 1897) published a series of USDA bulletins titled American Grasses. The dominant figure in agrostology into the 20th century was Albert Spear Hitchcock, born 1865 and died 1935. He was appointed assistant chief of the Division of Agrostology, USDA in 1901. In the following 34 years, Hitchcock produced over 250 publications and established himself as one of the truly great American botanists (Gould and Shaw 1968). The most significant of Hitchcock's publications were The Genera of Grasses of the United States with Special Reference to the Economic Species (1920) and Manual of Grasses (1935 and 1951). Throughout most of his career he was assisted by Mary Agnes Chase, who came to USDA as a botanical illustrator and became an assistant agrostologist in 1907 (Gould and Shaw 1968). After Hitchcock's death, she continued her work on grasses and published a revision of the Manual of Grasses in 1951. She became the Custodian of Grasses at the U. S. National Herbarium. We now have several excellent treatments of the grasses available. We all are aware of the recent taxonomic revisions in several grass genera, but how many generations of range managers and scientist have learned the grasses of the western range from Hitchcock's Manual of Grasses?

After the Forest Service was established, it became a required duty that range and forest personnel collect, press, and ship to headquarters botanical specimens. By 1937 the Forest Service herbarium contained 80,000 annotated specimens of 1,400 genera and 8,000 different species (Chapline 1937). They had been collected by an astonishing 1,200 different individuals.

\section{Agricultural Surveys}

At the end of the 19th century, the USDA began sending trained agriculturalists on surveys of the western range livestock industry. When the topographical engineering parties crossed the far west, there was no appreciable agriculture except in parts of the southwest. The
USDA surveys were designed to assess the nature of the range livestock industry that had grown since mid century. David Griffiths made several of these surveys. He was born in Aberistwyth, Wales in 1867 and emigrated to South Dakota. His undergraduate education was received at South Dakota Agricultural College and he received his Ph.D. from Columbia University in botany. His first professional employment was as a botanist with the Arizona Agricultural Experiment Station. When he conducted the range surveys, he was an assistant with the Division of Agrostology, USDA.

Under the title of "Expert in Charge of Field Management", Griffiths (1902) reported on a study titled, "Forage Conditions on the Northern Border of the Great Basin". The subtitle explained the bulletin was a report upon investigations made during July and August, 1901, in the region between Winnemucca, Nevada, and Ontario, Oregon. Even today, destination resorts are not abundant between these 2 towns. In the Preface to the bulletin, F. Lamson-Scribner, then Leader of the Grass and Forage Plant Investigations in the Bureau of Plant Industry, stated the purpose of the study was to investigate range conditions in an unknown region. LamsonScribner justified the study as showing the need for reforms in range management, a matter that applied not only to this remote area, but to the entire west. The Preface also contained the information that transportation, living expenses, and guides for Dr. Griffiths' 700 mile trip were provided by the superintendents of the Miller and Lux and Pacific Livestock Companies. At the time Miller and Lux was the largest ranching company in the far west. They boasted that you could ride from Canada to Mexico and stop at one of their ranches every night. Not surprisingly, among Griffiths' conclusions were that tramp sheepmen (see Coville below for definition) were over grazing summer ranges in the mountains that were traditional cattle ranges and practicing promiscuous burning. Apparently, it did not occur to him that over-grazing would have eliminated the herbaceous fuel necessary for promiscuous burning.

What did surveys such as the one conducted by Griffiths accomplish? At a time when the population center of the United States was east of the Mississippi, Griffiths' report and similar bulletins reporting on other such surveys gave the interested public and Congressional decision makers a view of an environment and type of agriculture that was completely 


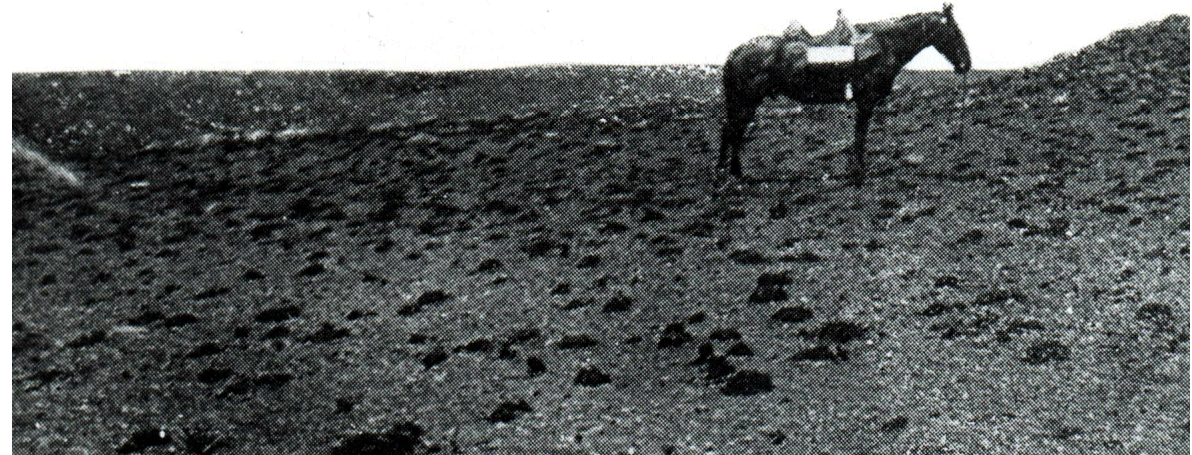

Fig. 1. Severely over grazed range on the Steen Mountains of eastern Oregon. Photograph taken by David Griffiths in 1901 during a survey of range conditions in the northern Great Basin. Such surveys helped to describe the range livestock industry which was based on public lands in the far west.

foreign to residents of the humid east. Griffiths literally brought views of the western range to the east because, although he traveled by buckboard, he hauled along a huge camera with which he recorded on glass plate negatives views of the desert rangelands. Perhaps, his most famous photograph showed the damage caused by excessive sheep grazing on the Steins (modern spelling Steen) Mountains of Oregon (Fig. 1). Griffths collected information on what plant species cattle and sheep preferred, or refused to eat, or which were reportedly poisonous.

Such surveys were not limited to Federal scientists. P. Beveridge Kennedy conducted and reported on 2 such surveys of the range sheep industry in Nevada at the beginning of the 20th century (Kennedy and Doten 1901, Kennedy 1903). Kennedy was born in Scotland, received his initial college education in Canada, and earned his Ph.D. at Cornell. His first professional experience started in 1899 with USDA, Division of Agrostology as an Expert in Charge of Field Management. It is little wonder he followed the same format as Griffiths, loading a large format camera in a buckboard and tracing the route of sheep bands across deserts and mountain ranges in their seasonal migration. Kennedy's photographs are probably even better than Griffiths', in that he took high contrast, close views of important forage species. Perhaps, his most famous photograph was a panoramic view of a very large band (3,000 head) of sheep taking their mid day "shading-up" break on a large snow bank in the high Sierra Nevada (Fig. 2).
During the first decade of the 20th century virtually every far western state had pioneering scientists who made tours of their state's rangelands trying to assess the problems facing the range livestock industry. The 55-day botanical expedition through New Mexico that was made by Elmer Ottis Wooton in 1904 is an outstanding example of such tours (Allred 1993).

\section{Visionary Scientists}

By the end of the 19th century the bloom was definitely gone from the western range. Virtually all available range was occupied and often over-utilized. Noted historian William Rowley sets the scene, "Before 1894, seventeen forest reserves with a total area of 17.5 million acres were under the Department of Interior and its land agency, the General Land Office. What the department was supposed to accomplish with the reserves other than protect the trees from depredation remained a mystery" (Rowley 1985). Officially the lands were closed, but no one knew if they were to be managed or if natural resources such as timber and grazing could be harvested from the reserves. Every Congressional attempt to define the management of the Forest Reserves ran afoul of one or more of the special interest groups such as mining, timber, grazing or watershed protection. An increasingly vocal conservation interest group was beginning to make its desires felt on a national level. A noted spokesperson for this loose federation of conservationists (we would now term them environmentalists) was John Muir of the Sierra Nevada of California. He submitted stirring articles to Century magazine on the evils of grazing mountain forest and rangelands.

The first official statement of administrative policy on grazing matters was in a regulation dated April 14, 1894 (Rowley 1985). On all Forest Reserves the "driving, feeding, grazing, pasturing, or herding of cattle and sheep, or other livestock is prohibited". As expected, this brought a howl of protest from western ranching interests. A National Academy of Science Committee was appointed to review the status of the reserves. The secretary and

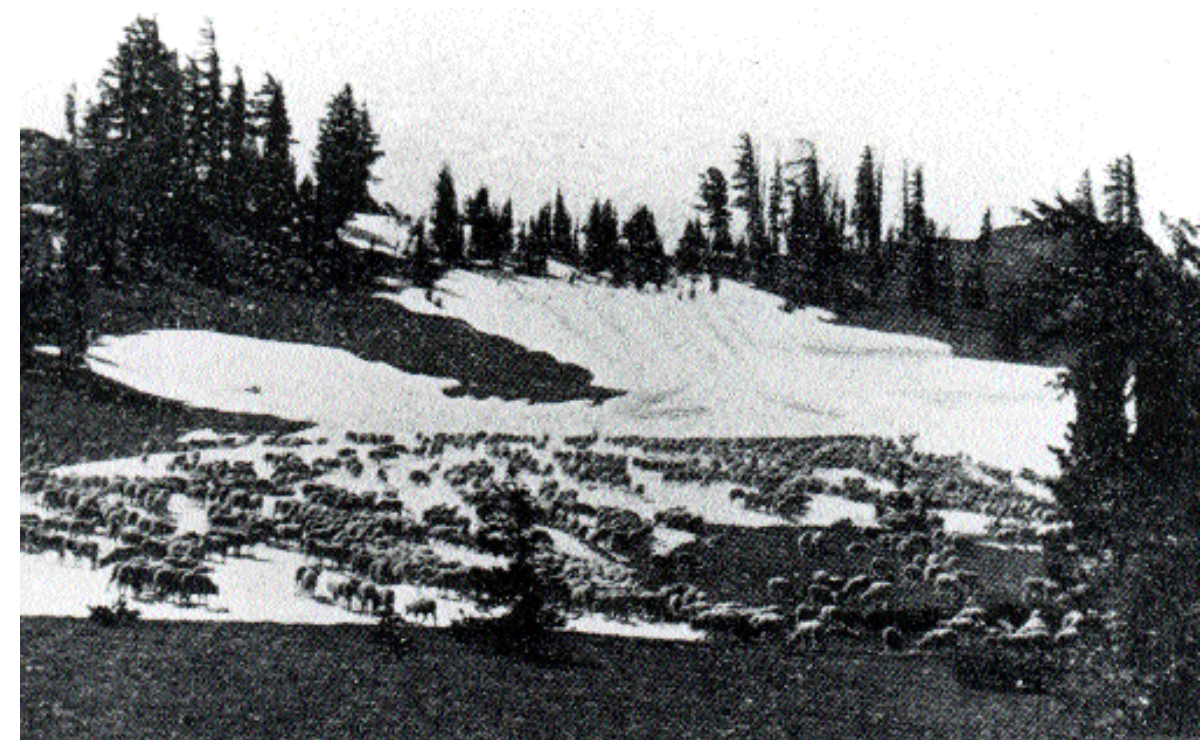

Fig. 2. A band of 3,000 range sheep resting during the mid-day heat on a snow bank in the high Sierra Nevada. Photograph taken by P. B. Kennedy in 1901. 
only forester on the committee was Gifford Pinchot. The chair was Charles S. Sargent, director of the Harvard Botanical Garden and author of Silva of North America (Pinchot 1947). Sargent had previously suggested that foresters, necessary to protect the Forest Reserves, should be trained at the United States Military Academy at West Point. At one time it was proposed that Federal troops should patrol and protect the Forest Reserves. At the time European, especially German, foresters were members of para-military organizations.

John Muir traveled with the committee as they toured the west and probably greatly influenced their decision to support a ban on grazing in the Forest Reserves. About the same time the report was released, outgoing President Grover Cleveland added over 21 million acres to the reserves. The report and the enlarged reserves brought more protest from the west and protracted Congressional debates and infighting in the form of amendments to appropriation bills (Rowley 1985). The end result was the issuance by the General Land Office of regulations permitting grazing of livestock except sheep on most of the Forest Reserves. Sheep were permitted to graze on the Cascade Forest Reserve located in Oregon and Washington.

During the period the Forest Reserves were in effect, USDA was supposed to be providing, in some vague way, technical guidance for the management of the reserves. Toward this goal, Frederick V. Coville was sent west in the summer of 1897 to assess the influence of sheep grazing on the Forest Reserves of Oregon and Washington. Coville was then Chief of the Division of Botany of USDA and was a strong proponent of a governmental system of leasing vacant rangeland to overcome the evils of over stocking and land misuse (Anon. 1944). Coville was born in New York in 1867. He completed his under graduate education at Cornell. His previous experience in the west was as a member of an expedition studying Death Valley during 1890-1891.

Binger Herman, Commissioner of the General Land Office, gave Coville a letter of introduction to the prominent sheepman John Minto of Salem, Ore. The rancher, who at the time was an outspoken opponent of John Muir, helped the botanist get started on his inspection. Coville left Klamath Falls in south-central Oregon on 23 July with 2 saddle horses and 5 pack animals. He reached The Dalles, Oregon, on the Columbia River on September 6th.

Coville was astounded to find sheep did not graze in fenced paddocks as was com- mon in the eastern United States, but were herded by a sheep herder who had to be constantly on guard to protect the animals from predators and to search for new areas to forage (Coville 1898). To reduce cost, each herder had to be responsible for as many animals as possible. These units of grazing sheep were called bands and consisted of 1,000 to 3,000 animals. This meant that the grazing of range sheep was concentrated in a relatively limited area each day. If the herder returned his flock to a fixed camp each night, the vegetation in the immediate neighborhood of the camp was devastated. Coville introduced the idea of trampling as the major damage caused by livestock grazing on the range.

As Coville wandered along the crest of the Oregon portion of the Cascade Mountains, he discussed the grazing of sheep with everyone he met. He discovered the movement of sheep to the mountains in summer had begun only 20 years before. Prior to that time sheep production in eastern Oregon had been based yearround on sagebrush (Artemisia)/bunchgrass rangelands. As the productivity of these rangelands had declined, sheep ranchers had moved to the high mountains in the summer for forage. This transhumance form of grazing had allowed sheep production in one county to increase from 6,000 to 25,000 animals. Coville used this as evidence of the importance of the high mountain ranges to the sheep industry.

The sheep bands were highly mobile. Coville considered the continued movement of several bands to be a sure indication of over-grazing. In the Three SistersUpper Deschutes portion of the Cascades he discovered 101,960 sheep that summer. Only 6,660 of these were considered local sheep from the adjoining county. The sheep from outside the local area or tramp sheep became an important issue throughout the mountains of the west. As Coville described the problem, "There is no law, except the questionable law of the Winchester, by which the rancher can defend his home, and he earnestly supports the demand for exclusion, believing that if sheep are kept out of the mountains the industry would be ruined and his own little range left free." (Coville 1898).

Coville was the first to state what has become a basic principle of range science. Grazing livestock on rangelands can be destructive if not managed. Managed grazing can be a sustainable use of rangelands. These statements are so deceptively simple it would seem ridiculous to consider them a foundation of range science. A century after Coville's studies, there is still a vocal segment of the environmental movement that considers any grazing of rangelands by domestic livestock to be an unacceptable use of the resource. Such individuals often choose not to distinguish between managed and destructive grazing. The question should be, is grazing a sustainable biological and physical process and if it is or is not, why?

In conclusion, Coville suggested that: 1) individual ranchers should be given the grazing rights on a specific range; 2 ) the number of animals permitted should not exceed the capacity of the forage resource on a sustainable basis; 3 ) in return, the rancher would agree not to burn promiscuously and to help suppress natural fires; and 4) the administrative cost of the program would be paid by the rancher in the form of a fee based on the number of animals grazed. There had to be an administrative fee because experience had shown that voluntary programs developed by grazing associations did not work. Someone had to enforce the rules. Coville saw nothing wrong with livestock being excluded from specific landscapes of great value to the public, such as Crater Lake in Oregon.

Note that Coville suggested that ranchers be given the right to graze specific portions of the public domain. In the 20th century when the Forest Service was established, grazing was classed as a privi lege and not a right. This policy was established because in Germany grazing rights in forest often dated from feudal times and caused endless problems for German foresters who were greatly admired by their American fledgling counterparts (Sampson 1919a).

Frederick Coville was a large scale, national scientist with a vision of the future. Each western state had similar visionary scientists interested in rangelands. Some were local or regional in their influence and some soared to national prominence. We have previously introduced P. B. Kennedy of the University of Nevada, who went on to prominence at the University of California at Berkeley. F. H. Hillman was a contemporary of Kennedy whose contributions were more local in character. Hillman was a botanist-naturalist who liked to walk the fields, meadows, and semi-arid rangelands near the Truckee River and observe the nature of things. He wrote in 1896, "On looking over the American literature upon our various forage plants, one can not fail to note the very meager information to be had relating to the many plants that are native to the 
western part of the United States" (Hillman 1896). Hillman compiled local floras and annotated lists of introduced weeds, each a building block toward the whole of understanding the western range. The first generation of range science was built by many such seemingly small contributions from scientists in many different states.

\section{Forest Service Period}

In 1905, when the Forest Service was established in the USDA and the Forest Reserves were transferred from USDI to become National Forests, there were millions of cattle, sheep, goats and horses grazing on these lands (Chapline 1937). The Forest Service, which was created from the former Bureau of Forestry, was primarily charged with protection of timber production and watersheds. In the west, livestock grazed over four-fifths of the area of the National Forest and these rangelands constituted $85 \%$ of the watershed for the major western rivers (Chapline 1937). The Secretary of Agriculture informed Chief Forester Pinchot, 4 days after the Forest Service was formed, that a probably jubilant General Lands Office had already set in motion a permit grazing system for 1905 for the former Forest Reserve lands (Rowley 1985). The General Lands Office was getting rid of more than 2 decades of grief. The Secretary of Agriculture charged Pinchot to use "whatever plan, in your judgement, will act for the best permanent use of the range." Pinchot believed the Forest Service had 3 essential jobs: protection, management, and the effective application of science (Rowley 1985).

The vast majority of the American population at the end of the 19th century was not far removed from the farm environment. This certainly applied to the majority of administrators in USDA. It was logical that the first attempts to restore deteriorated rangelands would involve planting forage species. It was also logical that the species of choice would be the perennial grasses redtop (Agrostis alba L.) and timothy (Phleum alpinum L.), both exotic species native to Eurasian. Today it would seem ludicrous to choose 2 exotic, invasive species adapted to humid pastures for seeding of rangelands in the west where they were only adapted to wet meadow or irrigated conditions. These 2 grasses had revolutionized forage production in the humid east. To the agricultural public east of the Mississippi River, they were the wonder forage plants of the 19 th century.
At the same time that redtop and timothy were being considered for the mountainous ranges of the far west P. B. Kennedy was writing with a thunderous pen, "When the average man begins to think about restoring depleted ranges, he is apt to imagine that somewhere on earth, in Australia, or South Africa, or even in Siberia, there must be a wonderful grass or salt bush, or something else which can be made to grow on his ranges high up on the dry mountains and down in the wooded dark valleys, furnishing abundant food for all his stock." (Kennedy and Doten 1901). Kennedy equated the chances of finding such a plant were the same as finding a cure in a 1 dollar bottle of patent medicine. He claimed the only adapted plants were those that grew on the range at the time, but Kennedy also considered the whole idea of government doing range improvement to be a socialist plot. Contemporaneously, F. H. Hillman mused, "How would we, if ever, domesticate the wonderful native bunchgrasses?" (Hillman 1896).

As early as 1902, USDA had scientists experimenting with the seeding of depleted meadows (Cotton 1908). Cotton was a scientific assistant with the farm management investigations unit of the Bureau of Plant Industry. The first plantings were seeded in 1902 on what later became the Wenatchee National Forest in Washington. The plots were established in cooperation with the Washington Agricultural Experiment Station. In 1903 he established similar experiments in northern California in the Sierra Nevada and Warner Mountains. Cotton used a wide variety of plant material, including several native grass species. He concluded that with proper seedbed preparation tame grasses could be established on degraded meadows.

The first Forest Service experiments with seeding began in 1907. The experiments were initiated by Arthur William Sampson who later was often credited with being the father of range management. Sampson was born in Oakland, Nebraska in 1884. He received his B. S. from the University of Nebraska in 1906, M. S. from John Hopkins in 1914, and his Ph.D. from George Washington University with a major in plant ecology and climatology (Anon. 1968). He had apparently just finished or was finishing his undergraduate degree, when he went to the Wallowa Mountains of northeastern Oregon to conduct seeding trials at high elevations sites.

In the forward to a preliminary report on the research, Frederick V. Coville explained the selection of the Wallowa National Forest (Sampson 1908). Much of the higher elevation portions of the Wallowa Mountains were grazed exclusively by sheep. An estimated 252,000 sheep grazed in the area in 1906 (Strickler and Hall 1980). Forage production had decreased so drastically that many of the sheepmen had proposed closing the range to grazing for a few years. Sending Sampson to conduct research on these degraded, high elevation ranges was in response to the sheep rancher's request for help. This is one of the few examples from the time period where the Federal government responded favorably to the sheep industry compared to cattle ranching.

Sampson's principle experimental site was called the Stanley (modern spelling Standley) Range and consisted of about 20 acres (Fig. 3). The site was severely overgrazed and had originally supported the bunchgrass green needlegrass (Stipa viridula Thin.). Sampson seeded timothy, redtop, and Kentucky bluegrass ( $P O a$ pratensis $\mathrm{L}$.). He reported on these trials in 1908 and 1909 with USDA Circulars and more completely with a USDA Bulletin in 1913 (Sampson 1908, 1909 and 1913a). In a footnote in the first Circular, Sampson reported he used the techniques of $\mathrm{F}$. E. Clements in his research. It is important to note that Sampson published preliminary results of these experiments in the 1908 and 1909 Circulars. Apparently, this reflects how badly the information was needed. By the time the 1913 bulletin was published, Sampson reported that the Forest Service had conducted some 500 seeding trials across the western forest. Sampson summarized his results: "It is not to be presumed, however, that all overgrazed ranges can be successfully reseeded to cultivated plants. On the contrary, it is unquestionably true that existing conditions in the major portion of the native grazing lands are antagonistic to the establishment of introduced plants, this is due to excessive elevation, poor soil, insufficient moisture, or too much too aggressive native vegetation" (Sampson 1913a).

Sampson established 2 points in this research that remain standards, 1) if you are going to seed on rangelands you have to prepare a seedbed, and 2) the seeded area has to be protected from grazing. Sampson was to develop such a monumental reputation in range science that his words became cast-in-stone for range managers. His early research became interpreted to mean that it was impossible to seed rangelands. This interpretation remained in force until the late 1930s and 

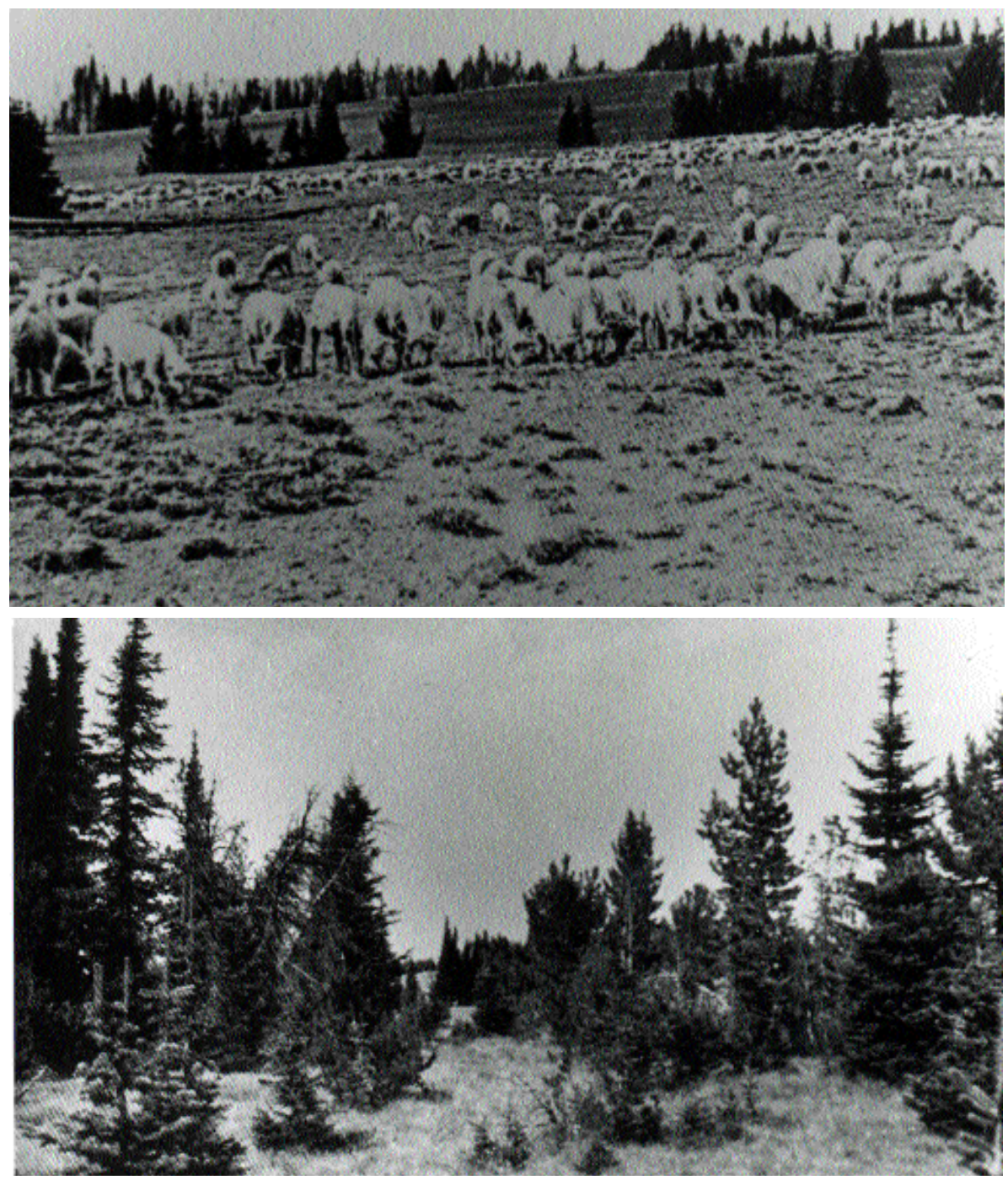

Fig. 3. [A] A portion the Standley sheep allotment in Wallowa National Forest in 1907. A. W. Sampson took the photograph of severely depleted rangeland he was trying to restore. [B] Photograph taken in exactly the same location in 1992 (from Skovlin and Thomas 1995). Subalpine fir (Abies lasiocarpa), whitebark pine (Pinus albiculis), and Engelmann spruce (Picea engelmannii) have invaded the former needlegrass (Stipa) grassland.

1940s when another generation of Forest Service scientists were successful with artificially seeding rangelands and expanding range restoration from only wet meadows to the vast sagebrush (Artemisia)/bunchgrass rangelands (Young and McKenzie 1982).

The Forest Service officially established an Office of Grazing Studies and appointed James J. Jardine as its head in 1910 (Anon. 1944) (Fig. 4). Jardine was to become one of the most influential individuals in range science and agricultural research in general during the first half of the 20th century. He was born in Cherry Creek, Idaho in 1881 . He received a B. S. from Utah College in 1905. Later he received honorary degrees from Kansas State, Clemson, and Utah State Universities. He was to leave the
Forest Service in 1920 to become the Director of the Oregon Agricultural Experiment Station where he remained until 1931, when he returned to USDA as Director of the Office of State Experiment Stations, a position in which he served until 1946. Jardine made many contributions to range science over his career, but his greatest initial achievement was the coauthoring of the USDA bulletin, Range Management on the National Forest which probably was designed as an instructional text for Forest Service Range Examiners (Jardine and Anderson 1919). The bulletin was lavishly illustrated with excellent photographs (Fig. 5) and it contained a list of references arranged by subject matter. The bulletin covered subjects from determining the appropriate class of livestock for differ- ent range environments, to how to collect plant specimens. It is not hard to imagine a fledgling range examiner sitting at a rough table in a log cabin in the wilderness studying by lantern light Jardine's instructions for managing the range.

Jardine had been conducting research during the period before 1910 when he became head of the Office of Grazing Studies. It was an unusual type of research inspired by Coville's concern that sheep had to be herded on the range. Jardine experimented with coyote (Canis latrans) proof fences for sheep (Jardine 1908 and 1910). These studies were conducted at Billy Meadows in the Wallowa Mountains of Oregon. His experiences during these studies led to his development of range resource inventory procedures that were adopted by the Forest Service as their standard range reconnaissance procedure (Anon. 1944). The basic procedure was not significantly changed until after World War II. These reconnaissance instructions were placed in the Forest Service Use Book. These shirt pocket sized books contained the rules and regulations governing grazing on the National Forest. A range examiner would not be caught out on the range without the latest edition. Chapline claimed that the Billy Meadows studies were the crucible where a generation of future range scientist learned their trade (Chapline 1937) (Fig. 6).

Forest Service dominance of range research in the far west did not mean it was the exclusive agency for research. The state agricultural experiment stations continued and expanded their role in answering problems on rangelands. At the same time Jardine was feeding sheep to coyotes, P. Beveridge Kennedy and a chemist Sanford C. Dinsmore were conducting forage digestion experiments with sheep on summer ranges (Kennedy and Dinsmore 1909). In the introduction to the bulletin reporting this work the authors said, "One important point that has been determined (in previous research by Kennedy) is that succulent plants and shrubs are preferred by sheep to the grasses. Before advocating any method for restoring the depleted ranges we thought we would like to find out from the standpoint of nutrition, as well as palatability, which plants would give the optimum return in mutton production for the labor involved." They built digestion stalls on Hunter Creek in the Carson Range of the Sierra Nevada and conducted their trials with freshly collected forage from the range (Fig. 7). They were among the very first to recognize that broad leaved herbaceous species were 


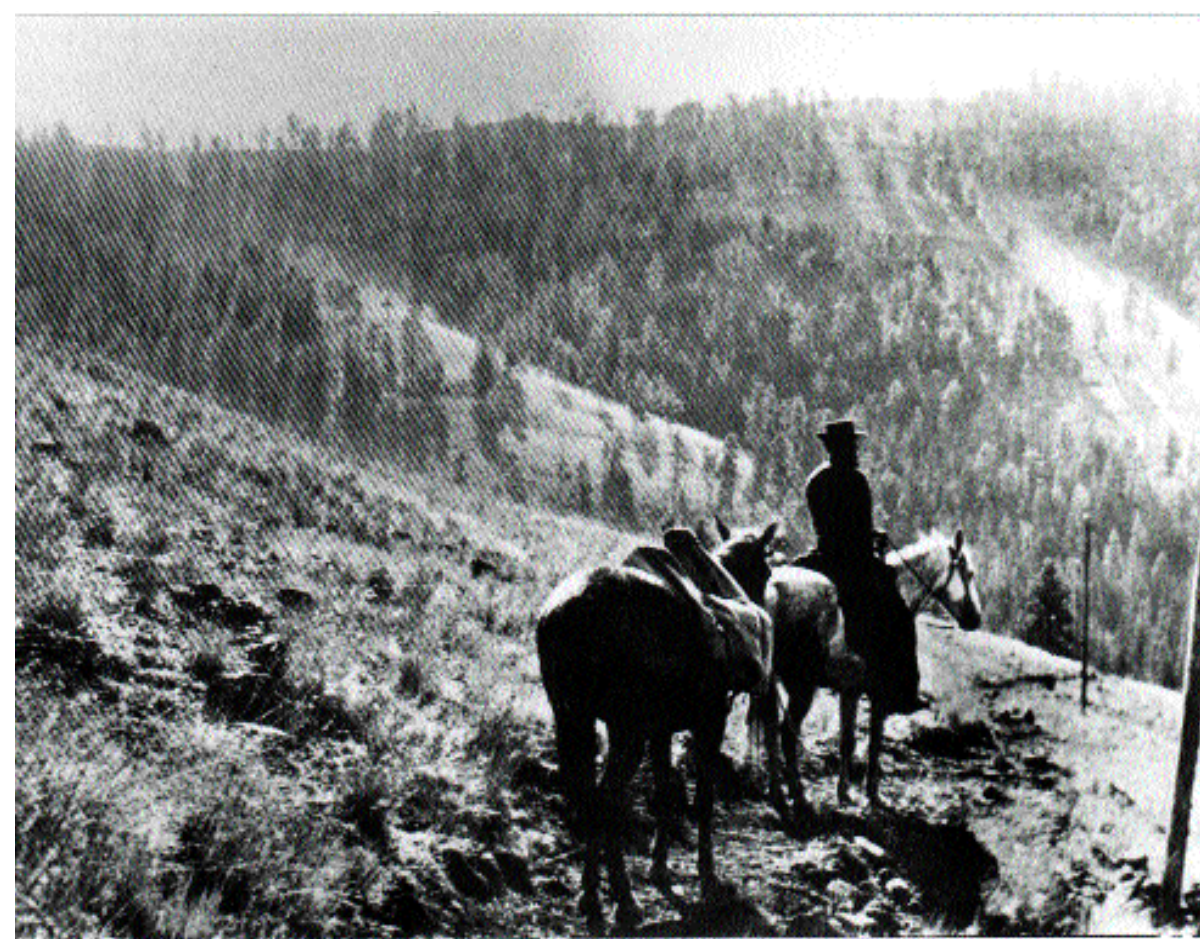

Fig. 4. James T. Jardine, first director of the USDA, Forest Service, Office of Grazing Studies that was established in 1910. In the photograph, Jardine is on the Chico Trail in Wallowa National Forest in 1907 (from Skovlin and Thomas 1995). Jardine was conducting research on range sheep grazing under fenced conditions at the time.

important in the diet of sheep. For some time after their work, the broadleaf herbaceous species, which we now term forbs, were called weeds in range research papers.

The Forest Service moved in 1910 to establish Offices of Grazing Studies in the Regional Forests that had been established as administrative units. The first field offices were established in 1911 in the Pacific Northwest, Intermountain, Rocky Mountain, and Southwestern regions with Charles E. Fleming, Alfred E. Aldous, Lynn H. Douglas, and Robert Hill in charge, respectively (Anon. 1944). Several of these individuals were to have careers in range research that extended into the 1940s.

The Forest Service launched into a new idea in range research by establishing experiment stations on the National Forest. The first was the Great Basin Experiment Station created in 1912 by administrative decision of Forester Henry S. Graves (Keck 1972). The headquarters unit is located in an aspen grove on the west front of the Wasatch Plateau in central Utah at an elevation of 8,500 feet. The first director of the station was A. W. Sampson. The Great Basin Station proved to be the site of perhaps his most noteworthy research.

The Great Basin Station was established, at least partially, because of the numerous letters the Secretary of Agriculture had received complaining of the numerous destructive floods that swept down from the forested range watersheds of the Wasatch Plateau to the towns and irrigated farm lands in the canyons and valleys below (Keck 1972).
Robert Reynolds, Forest Examiner, was perhaps the first to publish on the relation between grazing and watershed characteristics. Reynolds described the condition of the mountain ranges. "Settlement of the Sanpete Valley began about 1850, and the following 30 years saw a steady increase in the numbers of cattle and horses grazed on the mountains in the summer. Cattle numbers peaked in 1880 , about the same time a large range sheep industry developed. Sheep were wintered on desert ranges and spent their summers in the high aspen park lands at the head of the canyons of the Wasatch Plateau. Cattle and sheepmen fought for the use of the same range. The result was that, between 1888 and 1905, the Wasatch Range, from Thistle to Salina, was a vast dust bed, grazed, trampled and burned to the utmost.

.The basins at the head of the canyons suffered most, relatively, because they contained the best feed for sheep and were less broken in topography and more easily accessible.....These high mountain pastures, therefore, received not only the most abuse, but have been proportionately longer in recovering from its effects" (Reynolds 1911).

During the 19th and early 20th century, the sheep versus cattle conflicts were endless on the far western range. A. W. Sampson stated these conflicts were the greatest initial barrier to development of the range livestock industry after the Indian

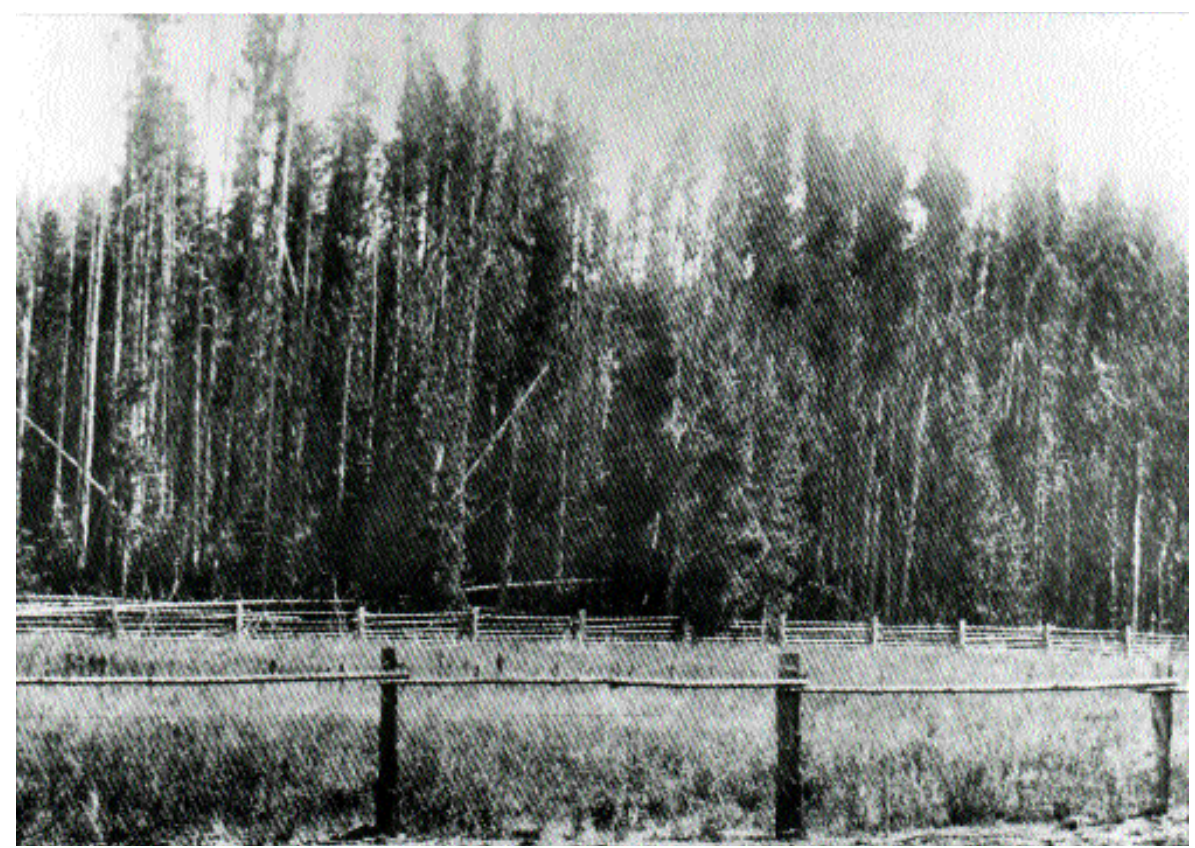

Fig. 5. Billy Meadows ranger station in Wallowa National Forest. This is the location where many of the first generation range scientist went to work sheep grazing and revegetation experiments. The fenced area in the fore ground was a grass nursery (from Skovlin and Thomas 1995). 

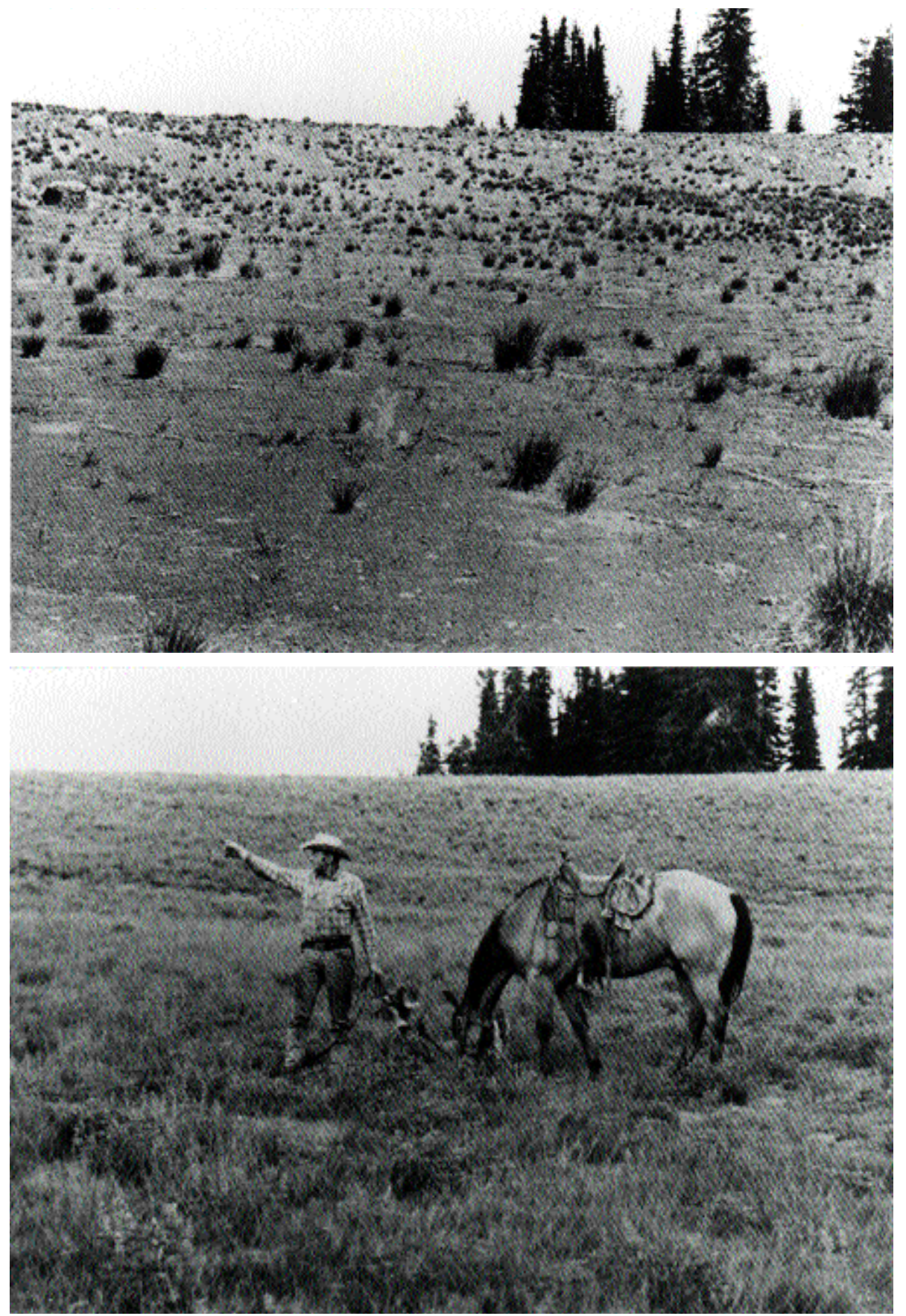

Fig. 6. [A] A photograph taken in 1917 of depleted range near Mammoth Springs, Baker County, Oregon. It was used by Jardine and Anderson (1919) to illustrate a site where reductions in grazing had started the process of restoration of the plant community. [B] Same site re-photographed in 1967 (from Skovlin and Thomas 1995). In 1967 the site was grazed by sheep and the herder is pointing to where the sheep will bed for the night.

wars and continued to be a barrier to management of the range (Sampson 1919a). Many portions of the National Forest that were established in Nevada were virtually without trees. Long established large cattle operations petitioned for their establishment in an attempt to control tramp sheep operations (Young and Sparks 1985).

The concern about the damaged watersheds, which were considered by many to articles based on research previously conducted in the Wallowa Mountains from 1907 through 1910. In the introduction to the Wallowa Mountains paper Sampson made this statement, "Ideal range management would mean the utilization of the forage crop in a way to maintain the lands at their highest state of productiveness and at the same time afford the greatest possible returns to the stock industry. To maintain the maximum productivity, the annual herbage crop must be used in a manner which will not retard the growth or prevent the perpetuation of the most desirable forage species" (Sampson 1914a). Sampson considered the decline in carrying capacity of the western grazing lands was brought about in part by injury due to trampling (Coville's great concern), but perhaps in greater part by premature graz ing and over stocking. He was recognizing a physiological influence on the plants besides physical destruction. Sampson built on the classical studies of $\mathrm{C}$. Hart Merrian (1898) in describing the various life zones of the Wallowa Mountains. He related plant phenology to life zones and in turn related these to the ability of the plants to resist grazing. Among his conclusions were, "Removal of the herbage year after year during the early part of the growing season weakens the plant, delays the resumption of growth, advances the time of maturity, and decreases the seed production and fertility of the seed" (Sampson 1914a). One of Sampson's basic building blocks of range science, that is often lost in modern grazing management, was, "Yearlong protection of the range favors plant growth and seed production, but does not insure the planting of seed. Moreover, it is impracticable, because of the entire loss of the forage crop and the danger resulting from the accumulations of inflammable material." Sampson suggested deferment of grazing until after seed ripe was the grazing management alternative most suited to restoring over grazed ranges.

With the benefit of hindsight, it has become obvious that Forest Service science and policy was making a huge error in regard to their policy towards suppression of all fires. At the time, promiscuous burning was viewed as a major threat to the forest (for example Plummer 1924). When these policies were formulated there were not a lot of wildfires on rangelands because of apparent lack of herbaceous fuel. In the first decade of National Forest in Nevada, virtually all rangeland, a total of 2,000 acres burned and in some years the total area burned was 10 acres (Plummer 1912). 


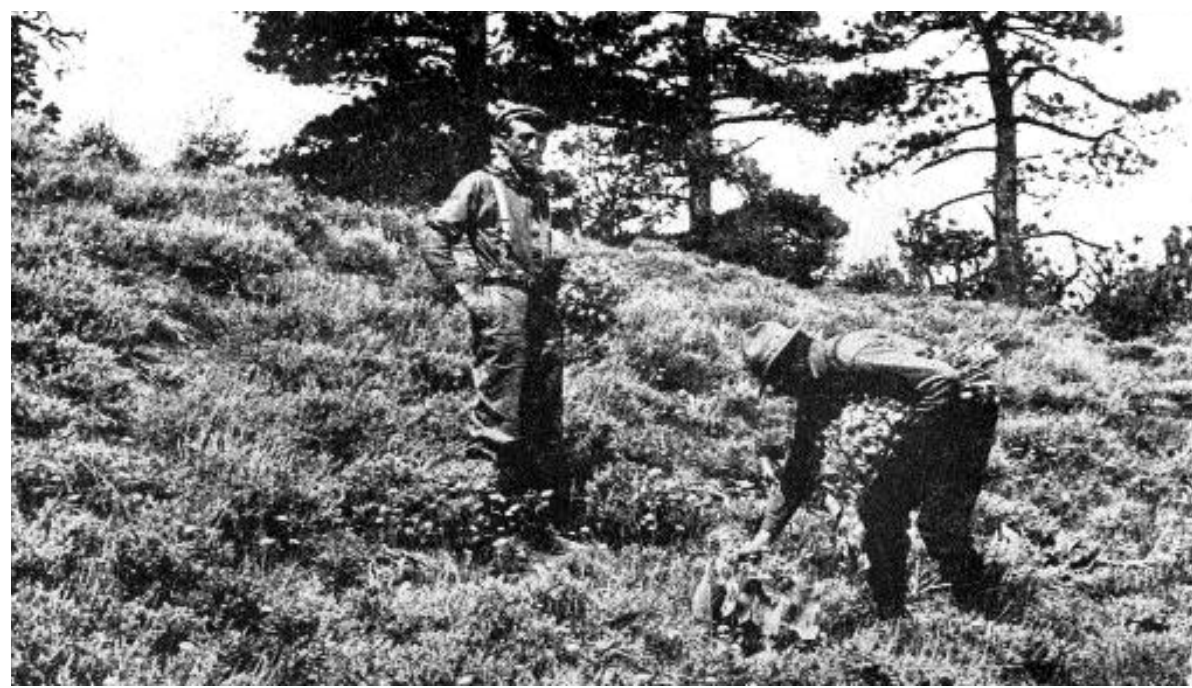

Fig. 7. P. Beveridge Kennedy and Sanford C. Dismore collecting forage species on summer range in the Sierra Nevada for use in digestion trials (Photograph from Kennedy and Dinsmore 1909).

One would think that A. W. Sampson would have been fully occupied with development of the Great Basin Experiment Station, especially as his personal research was establishing many of the fundamental principles of range science. Somehow Sampson found the time to write a series of articles on the basis of range management for the industry journal The National Wool Grower. This series apparently started in 1913 with an article entitled Scientific Range Management (Sampson 1913b) and continued the next year with Distribution and Function of Range Plants (Sampson 1914b). He continued over the remainder of the decade with articles on grasses and poisonous plants. He used scientific names for plants in these articles and explained technical points in plant identification and growth requirements. Sampson not only conducted highly original, appropriate research, he went a step beyond into technology transfer.

Perhaps the apex of A. W. Sampson's career as a research range scientist occurred with his publication Plant Succession In Relation To Range Management (Sampson 1919b). It is one of the few early research efforts he reported both as a journal article and a USDA bulletin (Sampson 1917 and 1919b). The article was only 3 pages long and reported a paper he had read at a meeting of the Botanical Society of Washington, D. C. The introduction to the bulletin states, apparently for the first time, several fundamental issues in range management. Sampson (1919b) stated, "Enterprising stockmen and those concerned with administration of grazing know that the livestock industry has now reached a point where the intensity of the use of the forage crop must be governed by a finer discrimination than mere observation of the density of the plant cover and the condition of the concept of the regular replacement of one assemblage of plants on a given site with another assemblage of plants in response to disturbance or freedom from disturbance. He used the term succession for this biological phenomenon. Sampson did not claim to have originated the concept of succession. In footnotes he cited Henry C. Cowles (1901), C. E. Moss (1910), and R. S. Hole (1911). Sampson suggested that the fundamental controlling processes in succession were simultaneous changes in the substratum. Plant growth influenced soil development and soil development controlled the composition and structure of plant communities. Sampson's bulletin was lavishly illustrated with drawings signed by A. E. Hoyle. The illustrations included both representations of individual plants and plants together in communities. Both types of illustrations featured above and below ground representations.

Sampson's conclusions thundered down from the Wasatch Front with the power of a snow slide or a summer flash flood and flowed across the desert ranges to reach all corners of the western range, "Grazing may cause either progression or retrogression succession, depending chiefly upon the closeness with which the herbage is grazed annually and the time when it is cropped" (italics added). Sampson reached a staggering 46 individually numbered conclusions that there was no question that much of the western range was over the stock". He introduced to range science conclusions. He set the stage in his first grazed. In conclusion number 3 he stated, "The most rational and reliable way of recognizing the incipient destruction of the forage supply is to note the replacement of one type of plant cover by another, a phenomenon which is usually much in evidence on lands used for the grazing of live stock". By recognizing the replacement of plant species he stated the concept of range condition, and by using the term incipient he obliquely referred to range trend.

A major problem for ranchers whose cattle grazed high mountain ranges in the west was the hazard of poisoning from consumption of larkspur (Delphinium sp.). It was estimated in 1917 that 5,000 head of cattle were poisoned annually on the National Forest (Aldous 1917). This was another of the cattle versus sheep issues, because sheep were not usually poisoned by tall larkspur because they did not prefer the species. Early research on poisonous plants was conducted by scientists employed by USDA, Bureau of Animal Industry and Plant Industry. The Forest Service conducted trials on the control of tall larkspur on several National Forest. Aldous (1917) reported on the efficacy and cost of hand grubbing as a control measure. It cost about $\$ 10.00$ per acre to grub tall larkspur plants by hand. This practice continued until World War II and hundreds of acres of high elevation rangeland were treated in this manner. Poisonous plant research became a major aspect of range science.

Federal research on all rangelands, public and private, was assigned to the Forest Service in 1915 (Chapline 1937). It remained this way until the McSweeneyMcNary Forest Research Act of 1928 provided a coordinated attack on all forest research and a 10 year financial program. Six bureaus within USDA either cooperated with the Forest Service or worked independently on range research. They were:

Bureau of Plant Industry-pastures and range revegetation, later plant breeding.

Bureau of Animal Industry - animal husbandry and poisonous plants.

Biological Survey-wildlife

Bureau of Entomology and Quarantineinsect problems

Bureau of Chemistry and Soils-plant analysis and soils

Bureau of Agricultural Economics

Forest Service experiment stations and research sites spread across the west during the 1920s. Among the earliest and most famous were the Jornada in New Mexico and Santa Rita in Arizona. Lincoln Ellison once stated that to be a successful first generation range scientist 
in the far west you had to have gained experience at either the Great Basin or the Jornada experiment stations (Keck 1972). Some were in cooperation with other USDA agencies such as the U. S. Range Experiment Station at Miles City, Mont. and the U. S. Sheep Experiment Station at Dubois, Ida. Stations such as the San Joaquin in California and Desert in Utah were located off National Forests and were designed to solve problems for ranchers when their animals were grazing off the forest. Forest Service scientists always chafed against the restriction that they could not work with the domestic range animals themselves, only with the ranges on which they grazed.

\section{Conclusion}

The first generation of range scientists established that the range livestock industry that used the National Forests for grazing must be regulated. This was a near revolutionary concept at the time. The researchers confirmed that productivity of many ranges was declining and accelerated erosion was common. They established a link between this decline and early season grazing year after year with no chance for the plants to flower and reproduce. Establishing the capacity of the range to support grazing on a sustainable basis was required to prevent over utilization of the resource. The crown jewel of scientific achievement by the first generation of range scientist was the innovative concept that changes in the species composition of plant assemblages provided the most biologically sensitive index of range condition.

In the early $1920 \mathrm{~s}$, several of the first generation range scientists left for university appointments. For example, A. W. Sampson went to the University of California at Berkeley and C. E. Fleming to the University of Nevada. It was becoming obvious that mistakes had been made in trying to optimize meat and wool production on the National Forest as a part of the World War I effort. In the post war years, agricultural depressions were to devastate livestock producers. Despite seemingly endless debate, millions of acres of vacant Federal rangelands outside the National Forest still received no management. Despite all this gloom and doom, a new generation of range scientists was to arise to build upon the achievements of the pioneers of the first generation.

\section{Literature Cited}

Aldous, A. E. 1917. Eradicating tall larkspur on cattle range in the national forest. USDA, Farmer's Bull. 826. Washington, D. C.

Allred, K. W. 1993. The trail of E. O. Wooton. New Mexico Resources. 9(Spring):3-17

Anon. 1924. Forest fires in the Intermountain Region. USDA, Forest Service, Misc. Cir. 19, Washington, D. C.

Anon. 1944. The history of western range research. Agricultural History 18:127-143.

Anon. 1968. Arthur W. Sampson (obituary). J. Range Manage. 20:103.

Chapline, W. R. 1937. Range research in the United States. Herbage Rev. 5:1-13.

Coville, F. V. 1898. Forest growth and sheep grazing in the Cascade Mountains of Oregon. USDA, Div. of Forest. Bull. No. 15. Washington, D. C.

Cotton, J. S. 1908. The improvements of mountain meadows. USDA, Bur. Plant Industry Bull. 127, Washington, D. C.

Cowles, H. C. 1901. The physiographic ecology of Chicago and vicinity. Bot. Gaz. 31:73-108.

Gould, F. W. and R. B. Shaw. 1968. Grass systematics. 2nd ed. Texas A\&M Univ. Press, College Station, Tex.

Griffiths, D. 1902. Forage conditions on the northern border of the Great Basin. USDA Bur. Plant Industry Bull. 15, Washington, D. C.

Hillman, F. H. 1896. Field notes on some Nevada grasses. Nevada Agr. Exp. Sta. Bull. 39. Reno, Nev

Hitchcock, A. S. 1920. The genera of grasses of the United States, with special reference to the economic species. USDA, Bull. 772, Washington, D. C.

Hitchcock, A. S. 1935. Manuel of grasses of the United States. USDA, Misc. Publ. 200 Washington, D. C.

Hitchcock, A. S. 1951. Manuel of grasses of the United States. 2nd ed. (revised by Agnes Chase). USDA, Misc. Publ. 200, Washington, D. C.

Hole, R. S. 1911. On some Indian forest grasses and their ecology. Indian Forest Memoirs 1:13-16.

Jardine, J. T. 1908. Preliminary report on grazing experiments in a coyote-proof pasture. USDA, For. Serv. Cir. 156, Washington, D. C.

Jardine, J. T. 1910. The pasture system for handling range sheep investigations during 1909. USDA, Forest Serv. Cir. 178, Washington, D. C.

Jardine J. T. and M. Anderson. 1919. Range Management on the National Forest. USDA, Bull. 790, Washington, D. C

Keck, W. M. 1972. Great Basin station. USDA, Forest Service, Res. Paper 118 , Odgen, Ut.

Kennedy, P. B. 1903. Summer ranges of eastern Nevada sheep. Nevada Agr. Exp. Sta. Bull. 55, Reno, Nev.

Kennedy, P. B. and S. C. Dinsmore. 1909 Digestion experiments on the Range. Nevada Agr. Exp. Sta. Bull. 71, Reno, Nev.
Kennedy, P. B. and S. B. Doten. 1901. A preliminary report on the summer ranges of western Nevada sheep. Nevada Agr. Exp. Sta. Bull. 51, Reno, Nev.

Lamson-Scribner, F. 1897. American grasses. USDA, Agrostology Bull. 7, Washington, D. C.

Merriam, C. H. 1898. Life zones and crop zones of the United States. USDA, Div. of Biol. Surv., Bull. 10, Washington, D. C.

Moss, C. E. 1910. The fundamental units of vegetation. New Phytologist 9:36-37.

Pinchot, G. 1947. Breaking new ground. Harcourt, Brace, and Co., New York, N. Y.

Plummer, F. G. 1912. Forest fires. USDA, Forest Service Bull. 117, Washington, D. C.

Reynolds, R. V. R. 1911. Grazing and floods: a study of conditions in the Manti National Forest, Utah. USDA, Forest Serv. Bull. 91, Washington, D. C.

Rowley, W. D. 1985. U. S. Forest Service grazing and rangelands. Texas A\&M Univ. Press, College Station, Tex.

Sampson, A. W. 1908. The revegetation of overgrazed range areas. USDA, Forest Serv., Cir. 158, Washington, D. C.

Sampson, A. W. 1909. Revegetation of depleted mountain grazing lands. USDA, Forest Serv., Cir. 169, Washington, D. C.

Sampson, A. W. 1913a. The reseeding of depleted grazing lands to cultivated forage plants. USDA Bull. 4, Washington, D. C.

Sampson, A. W. 1913b. Scientific range management. Nat. Wool Grower 3(12):7-9.

Sampson, A. W. 1914a. Natural revegetation of rangelands based upon growth requirements and life history of the vegetation. J. Agr. Res. 3:93-148.

Sampson, A. W. 1914b. Distribution and functions of range plants. Nat. Wool Grower 4(12):20-23

Sampson, A. W. 1917. Succession as a factor in range management. J. Forest. 15:593-596.

Sampson, A. W. 1919a. Suggestions for instruction in range management. J. Forest. 17:523-545.

Sampson, A. W. 1919b. Plant succession in relation to range management. USDA, Bull. 791. Washington, D. C.

Skovlin, J. M. and J. W. Thomas. 1995. Interpreting long-term trends in Blue Mountain ecosystems from repeat photographs. USDA, Forest Service, Res. Paper 315, Portland, Ore.

Strickler, G. S. and W. B. Hall. 1980. The Standley allotment: A history of range recovery. USDA, Forest Service, Res. Paper 278, Portland, Ore.

Vasey, G. 1890. Illustrations of North American grasses. Vol. I. Grasses of the Southwest. USDA, Botany Bull. 12, Washington, D. C

Wheeler, G. M. 1878. U. S. Geographical surveys west of the one hundredth meridian. Vol, VI. J. T. Rothrock (ed.). Gov. Printing Office, Washington, D. C.

Young, J. A. and D. McKenzie. 1982. Rangeland drill. Rangelands 4:108-113.

Young, J. A. and B. A. Sparks. 1985. Cattle in the cold desert. Utah State Univer. Press, Logan, Ut. 